\title{
Enhancing Firm Performance Through Adoption of Innovation: an Empirical Evidence from Indian Biotechnological Firms
}

\author{
Aishwarya Narayan ${ }^{1} \cdot$ Sumukh Hungund ${ }^{2}$
}

Received: 2 December 2020 / Accepted: 30 June 2021 / Published online: 14 July 2021

(c) The Author(s) 2021

\begin{abstract}
This paper explores the influence of innovation approaches on innovation performance and firm performance among Indian biotechnology firms. Further, it aims to discuss the interceding role of innovation performance between innovation practices and firm performance. A criteria-based snowball sampling method was adopted for data collection. The collection of data was carried out using a web survey from 200 biotechnology firms located across India. The data is analysed using a covariance-based structural equation modelling (SEM) technique. The results indicate that the adoption of innovation practices positively influences the firms' innovation and overall performance. Furthermore, the results confirm the mediating role of innovation performance between innovation approach adoption and firm performance. Firms, particularly from the biotechnology industry, can use these results to assess their performance and formulate or modify their strategy to improve their innovation and overall performance.
\end{abstract}

Keywords Open innovation approach · Closed innovation approach · Innovation practices $\cdot$ Firm performance $\cdot$ Innovation performance $\cdot$ Biotechnology firms

\section{Introduction}

The perception that innovation created by the businesses themselves is based on the closed innovation concept. This innovation occurs entirely within the companies, starting from idea creation to idea development and making it specifically

Sumukh Hungund

sumukh.hungund@manipal.edu

Aishwarya Narayan

aishwarya.narayan20@gmail.com

1 Graduate School of Business and Law, RMIT University, Melbourne, Australia

2 Humanities and Management, Manipal Institute of Technology, Manipal Academy of Higher Education, Manipal, India 
defined within the company limits. Certain factors need to be considered to establish closed innovation in an organization effectively. Closed innovation puts exceptionally high demands on employees, and the organization plans to hire more skilled staff. Moreover, the company must protect its intellectual property (Chesbrough \& Euchner, 2011).

By convention, firms heavily focused on closed innovation practices (development of patents, intellectual rights through internal research and development) to gain a competitive advantage (Chesbrough \& Euchner, 2011). However, due to shorter cycles of innovation, higher research and development (R\&D) cost, and shrinking resources, firms embrace open innovation as their competitive strategy (Enkel \& Gassmann, 2010). Chesbrough (2003a) discusses open innovation as "the utilization of purposive inflows and outflows of information to quicken internal innovation and grow the business sectors." Open innovation expects the firms to keep a porous boundary with their surrounding environment so that the innovation movement quickly takes place between internal and external factors (Chesbrough \& Euchner, 2011).

The firms' resources are involved in building R\&D capacities to expand innovation through change, administrations, and procedures (Un \& Rodríguez, 2018). In general, studies related to open innovation are positioned high on development and innovation (Enkel \& Gassmann, 2010; Vanhaverbeke, 2009). Cohen and Levinthal (2009) argue that external information is an essential part of innovation performance. Innovative firms adopt open innovation approaches by utilizing various external resources to accomplish firms' objectives (Chesbrough, 2003a, 2003b; Perez et al., 2019). This study characterizes open innovation as "another paradigm" that clarifies why firms ought to popularize external information for organizational development (Chesbrough, 2003b, 2006; Enkel \& Gassmann, 2010; Hungund \& Kiran, 2017; Perez et al., 2019; West \& Gallagher, 2006). Previous studies (Katila \& Ahuja, 2002) have also demonstrated that the character of a company's internal technique and external information can influence its innovation performance.

While extensive research concerning open innovation revolves around technically inclined enterprises, research on conventional ventures such as biotechnology, SMEs are limited. The biotechnological industry is an important industry that includes pharmaceutical, manufacturing, food, research, and healthcare services (Bianchi et al., 2011). A systematic vast-scale analysis gives us a clear understanding of the open and closed approaches to innovation that companies adopt and explains how these strategies affect the firm's efficiency.

In a similar vein, studies in the literature have concentrated more on open innovation approaches, firm performance, and innovation performance (Lofsten, 2014; Oltra et al., 2018; Michelino et al., 2016; Caputo et al., 2016). However, the impact of closed innovation practices on innovation performance and firm performance has been scant. Furthermore, the interceding role of innovation performance relating to innovation practices and firm performance is ignored (Agostini et al., 2014; Huang et al., 2009; Inauen \& Schenker-Wicki, 2011). Innovation practices and their benefits are contextual; as seen in the literature, these links among 
biotechnology firms are rarely investigated (Hungund \& Kiran, 2017; Kafouros \& Forsan, 2012).

This study proposes to fill the void by measuring the influence of closed and open innovation approaches on innovation performance and firm performance in the Indian biotechnology industry, also to explore the mediation role of innovation performance concerning innovation practices and firm performance. The rationale for choosing the Indian biotechnology industry is as follows: (i) it is a highly innovative industry and plays a significant role in the Indian manufacturing sector, (ii) India has the second-highest number of US Food and Drug Administration (USFDA) approved plants, ${ }^{1}$ (iii) India is among the top 12 biotechnology destinations in the world and ranks third in the Asia-Pacific region, and (iv) biotechnology industry is highly dependent on both closed and open innovation approaches.

The objectives of the study are as follows:

1. To examine the influence of "closed and open innovation" practices on innovation performance and firm performance.

2. To examine the interceding role of innovation performance between innovation practices and firm performance.

This paper investigates the intermediate role of innovation performance as a plausible third variable compared to past studies' results. The testing of this mediating theoretical linkage between the two constructs has not been discussed earlier.

The paper is structured as follows: "Background Literature" focuses on background literature; "Hypothesis Development" highlights the hypotheses; "Conceptual Framework" discusses the conceptual framework; "Research Design" mentions the research methodology; "Result Analysis" reports and discusses the findings and results. In "Discussion and Managerial Implications," discussion and managerial implications are provided. Finally, in "Conclusion and Limitations," the conclusions and limitations of the study are presented.

\section{Background Literature}

\section{Closed Innovation and Open Innovation}

Large companies have traditionally focused on internal research and development to develop new products. Wide internal R\&D laboratories were a competitive advantage in many sectors and constituted a significant deterrent to possible competitors. Consequently, major corporations with increased R\&D capacity and comparable resources could surpass smaller competitors (Bogers, 2011; Oltra et al., 2018). The closed innovation model has been designated as this mechanism in which large companies find, grow, and market innovations internally (Chesbrough, 2007; Luoma

\footnotetext{
$\overline{1}$ https://www.ibef.org/industry/biotechnology-india.aspx; last retrieved on June 18, 2019.
} 
et al., 2010; Prahalad \& Ramaswamy, 2004). While this paradigm has been working well for quite a while, the new world of creativity has changed.

Because of labour mobility, an abundance of risk resources, and the vast scope of expertise between several small and large businesses, companies can no longer afford to innovate by themselves (Guthrie \& Petty, 2000). As a result, an increasing number of multinational enterprises have evolved into an open innovation paradigm that uses both domestic and foreign methods to leverage and gain information from external sources simultaneously (Hungund \& Kiran, 2017; Xia \& Roper, 2008). The wide-ranging definition of open innovation covers many aspects.

In accordance with the above description, most studies differentiate between targeted flows of output and information inflows for accelerating internal innovation processes and better benefiting from creative efforts (e.g., Chesbrough, 2006; Chesbrough, 2007; Lettl et al., 2006; Laursen \& Salter, 2006; Piller \& Walcher, 2006; Chesbrough \& Crowther, 2006). Purposeful expertise or technical exploitation outflows include engineering activity to harness emerging technological resources beyond the organization's borders (Agostini et al., 2015). Purposeful inflows, also known as technology exploration, are innovation activities that include gathering and learning from external data sources to promote new technical advancements (Villasalero \& Villasalero, 2018). Companies merge technical and technology discovery in a completely open environment to achieve the highest benefit through their technological expertise or other skills (Chesbrough \& Crowther, 2006; Lichtenthaler \& Lichtenthaler, 2008).

As per Belderbos et al. (2004), the biotechnology industry has portrayed a significant task in updating and encouraging the open innovation model. The collection of methods for handling the partnership is another advantage of open innovation (Terziovski, 2003). Biotechnology firms are seeking to thrive in the market by entering into supplier-client alliances with larger firms (Luukkonen, 2005), outsourcing information with different firms (Ortt \& Smits, 2006), or with multi-firm systems (Tidd \& Trewhella, 1997). Other researchers have investigated the collaboration in various periods of the innovation procedure (Enkel et al., 2009; Roberts, 2001).

\section{Innovation Performance}

As per Darroch (2005), organizations with a stronger focus on these innovation tactics, who have experience of collaboration and other innovation practices and use of this information and assets more productively, are more profitable. The open innovation practices further contribute to the growth by knowledge management methods (De Brentani \& Kleinschmidt, 2004) to impact new product development and business innovation success (Agostini et al., 2015). To support these statements, Laursen and Salter (2006) examine the connection between the importance and rates of company purchases on demand for new goods by utilizing innovation practices known to improve innovation performance. Hurmelinna-Laukkanen et al. (2008) concluded that there was a gradual beneficial outcome in innovation performance when there is a process of exchange of external knowledge between SMEs. Study on the impact of open innovation on innovation performance has, however, not been studied 
separately. Literature shows that business collaborations and partnerships have been essential precursors to innovation performance successes (Agostini et al., 2014). The current study provides insights into the connection between innovation approaches and the innovation performance of biotechnology companies in India. The study examines the issue by concentrating on the theories in settings portrayed by various dimensions of open innovation practices measured by multiple parameters, including patents, trademarks, and trade secrets, among other variables.

\section{Firm Performance}

The association between innovation performance and the corporate firm performance of organizations is not consistently agreed upon. New capabilities, shared production costs and hazards, reduced time for promotion, increased innovation practices, market share openings, and the acquisition of patents and trademarks affect firm performance success (Dreschler \& Natter, 2012; Tidd, 2014). Although innovation performance can also be damaging to corporate firm performance, research has shown that successful results overcome the negative ones, revealing a positive link between innovation performance and business performance (Bengtsson et al., 2015; Chiang \& Hung, 2010). Given the benefits, companies need to take internal and external approaches to innovation (Lichtenthaler \& Ernst, 2009), expand agreements (Huang et al., 2009; Chaston \& Scott, 2012), and update their knowledge to better work on their research and development (Villasalero \& Villasalero, 2018). Xia and Roper (2008) have also discovered and have negatively four open innovation metrics for high innovation in organizations. Furthermore, Van de Vrande et al. (2009) stated that research and development programs involving open innovation organizations have evidence of innovative monetary successes.

Nevertheless, a few research reviews confirm a positive effect (bearing and cost) when introducing open innovation practices within organizations (Vishnu \& Gupta, 2014; Amin \& Aslam, 2017; Nadeem et al., 2018; Noor et al., 2015; Roberts, 2001). The above brief analysis of firm performance proposes that the fundamental context should include three key considerations in response to firm performance: the various modes of open innovation, the type of innovation performance, and its impact on firm performance. Our examination will investigate how the connections between the three factors have developed over time in the biotechnological industry in India.

\section{Theoretical Framework}

Innovation resources are the key drivers of an association's prosperity that undertake an essential job of value creation and improve the inclusive firm performance by constantly increasing business activity and innovative thinking (Chesbrough, 2006; Enkel \& Gassmann, 2010). The appropriate utilization of innovation is a test for organizations due to the market's inconsistent and dynamic growth (Chesbrough, 2003a). The innovation approach model of Chesbrough (2003a) and its effects on the industry's various output parameters should be individually analyzed to recognize the organization's moves to execute pioneering thinking to pursue future business 
estimates. According to Chesbrough (2003b), open innovation theory explores innovations from internal and external sources to increase their existing ideas.

The critical distinction between closed and open approaches to innovation is external sources to apply concepts and information. Several external sources, like collaboration, intellectual property, alliances, and spin-offs, can implement open innovation in the firm. Firms in the biotechnology industry, for the most part, have constrained internal data sources and monetary assets for checking and observing innovative conditions. Moreover, they need capacities to successfully assemble, distribute, and promote innovations (Narula, 2004). The accessibility of talented specialists, the versatility of assets, and the expanding ability of external suppliers have influenced the innovation worldview. Likewise, Chesbrough (2003b) maintains that adopting an innovation plan contributes to the firm's success and is influenced by the relevant variables. Additionally, Perez et al. (2019) concluded that the conceptual variables impacted the company's technology innovation approach. Thus, Chesbrough's theory of innovation is utilized in the current study.

\section{Hypothesis Development}

When studying organizational success, asset-based theory perceives open innovation and closed innovation as critical entities to increase firm efficiency (Bruton \& Rubanik, 2002). This is further corroborated by the works of Burpitt and Bigoness (1997) and Firer and Williams (2003). This theory fundamental provides a positive relationship between open innovation and innovation performance, further affecting the firm's performance. However, in biotechnological firms, this relationship is not looked upon closely, leading to a certain number of gaps and studies.

The standard approach to coping with a business environment that relies on ownership and control is achieved using closed innovation activity. The closed innovation adopts a direct strategy as partnerships rely solely on inner skills (e.g., internal research and development $(\mathrm{R} \& \mathrm{D})$ process and practices for generating and thinking ideas) and practices that promote internal innovation projects (Lichtenthaler \& Lichtenthaler, 2008). Also, companies found that another way to deal with innovation is working on client issues and searching for innovations or ideas and knowledge remotely (Conboy \& Morgan, 2011). Outstandingly, a significant gap exists in the functional utilization of closed innovation approaches (Enkel \& Gassmann, 2010; West \& Bogers, 2013). Overall, organizations begin to perceive the constraints of their internal R\&D practices.

Moreover, they understand that to flourish, and they have to discover better learning and innovation approaches in an undeniably intricate and competitive condition. Nevertheless, considering traditional innovation methods, the study considers the extent to which closed innovation affects innovation performance. Hence, there is a need to test the following hypothesis:

$\mathbf{H}_{1}$ : Adoption of closed innovation approaches has a positive impact on the innovation performance 
Numerous organizations are developing and revamping their innovation framework from a closed to open innovation (Chesbrough \& Crowther, 2006; Chesbrough, 2003a). While open innovation models have considerable advantages for R\&Dcentric organizations in advanced industries, little thought is given to their effect on innovation success in traditional industrial sectors (Chesbrough \& Crowther, 2006; Laursen \& Salter, 2006) more so when it comes to biotechnological industries. This study includes R\&D organizations within segments to resolve this gap in research and fewer R\&D organizations in other fields to determine their impact on innovation efficiency by focusing on their open innovation practices. Therefore, the second hypothesis is as follows:

$\mathbf{H}_{2}$ : Adoption of open innovation approaches has a positive impact on innovation performance.

Innovation performance is the most significant factor in the business performance of a firm. It further allows the company to maximize the impact of innovation performance with firm performance and aligns performance goals and investment decisions. Using Schumpeter's (1934, 1939) classification system, innovation performance measures can be as follows: new production methods, new supply sources, new market exploitation, new ways to organize business, and new products. Firm performance is used to analyse and align the company's needs of business, strategies, and goals with innovation performance management plans to measure, direct, and communicate the objectives of improved success rate, reduced time to market, and increased new product value. Chen et al. (2005) showed that innovative performance plays a role between innovative acts and firm performance in Turkish manufacturing enterprises. Hence, to analyse this effect in biotechnological firms, it is hypothesized:

$\mathbf{H}_{3}$ : Innovation performance significantly helps to improve firm performance.

Chesbrough (2012) indicated that a normal for closed innovation practices is that the firm's science and innovation base is the driving force behind the innovation projects. Chesbrough \&Euchner (2011) depicts the procedure as all undertakings touch base at the firm performance procedure; some are halted, while others are viewed as possibly making quality and are chosen for further work. The "closeness" is characterized by the tendency to enter and leave the market in one direction (infiltration into the market). After creating open innovation through this single direction process, firms must safeguard their licensed innovation against rivalry and further their firm performance. Hence, it is hypothesized that.

$\mathbf{H}_{4}$ : Adoption of closed innovation approaches has a positive impact on firm performance.

Hungund and Kiran (2017) contemplate the data sourcing practices and found that none of the open innovation practices considered are positively associated with the firm's performance. Clarke et al. (2011) demonstrated a positive relationship of 
innovation deals per representative on a diverse performance estimation. The business edge is not fundamentally affected by innovation yield for that sector of the industry. Bianchi et al. (2011) demonstrated that there was a need for innovation and profitability. In this respect, while companies using open innovation grow more rapidly in deals, businesses, capital, effectiveness, etc. This absence may be the consequence of the diverse set of the examination. Therefore, it is hypothesised that.

$\mathbf{H}_{5}$ : Adoption of open innovation approaches has a positive impact on firm performance.

\section{Mediating Role of Innovation Performance}

The current literature suggests several factors influencing an organization's decision to participate in innovation activities and innovation output (Wadho \& Chaudhry, 2018). One of the crucial stages in innovation is the change of innovation input into innovation output. The essential contribution to the generation of innovation is to invest in the development of both R\&D and otherwise. The underlying hypothesis proposes a positive effect of innovation performance on firm performance. Previous research has shown a positive influence of innovation performance on firm performance in most experimental investigations (Lofsten, 2014; Wadho \& Chaudhry, 2018; Michelino et al., 2016; Caputo et al., 2016; Amin \& Aslam, 2017).

Researchers and specialists opine innovation performance as an essential component in business (Jaekel et al., 2015). Organizations focus on carrying out innovation to make them aggressive and stand out when the business activities change. It serves as a vital method for the creation and building of new markets. Hence, innovation performance is presented between innovation approaches (both closed and open) and firm performance to encourage organizations' performance.

$\mathbf{H}_{6}$ : Firm's innovation performance mediates between closed innovation approaches and the firm's performance

A business being innovation-oriented is considered aggressive. It will create new solutions, develop and enhance new products and ideas that align with the company (Hungund \& Kiran, 2017; Rakthai et al., 2019). There is accordingly a requirement for organizations that embrace the innovation approach in their line of activity to take a gander at thinking about innovation performance in their exercises. Wadho and Chaudhry (2018) examined relationship between innovation performance, innovation approaches, and firm performance and demonstrated a decent connection between innovation approaches and firm performance. In this way, it is estimated that innovation performance would intercede the connection linking innovation approaches and firm performance.

Nieto and Santamaria (2010) argued that unmistakable structures influence performance in innovation and firms. Enkel and Bader (2012) found that hierarchical frameworks related to coordination limits enhance the anchoring and stream of new external data. Medsker et al. (1994) claimed that the critical breakthrough points often affect innovation efficiency. Lichtenthaler and Ernst (2009) demonstrated that collaboration is decidedly identified with the change, particularly the associations 


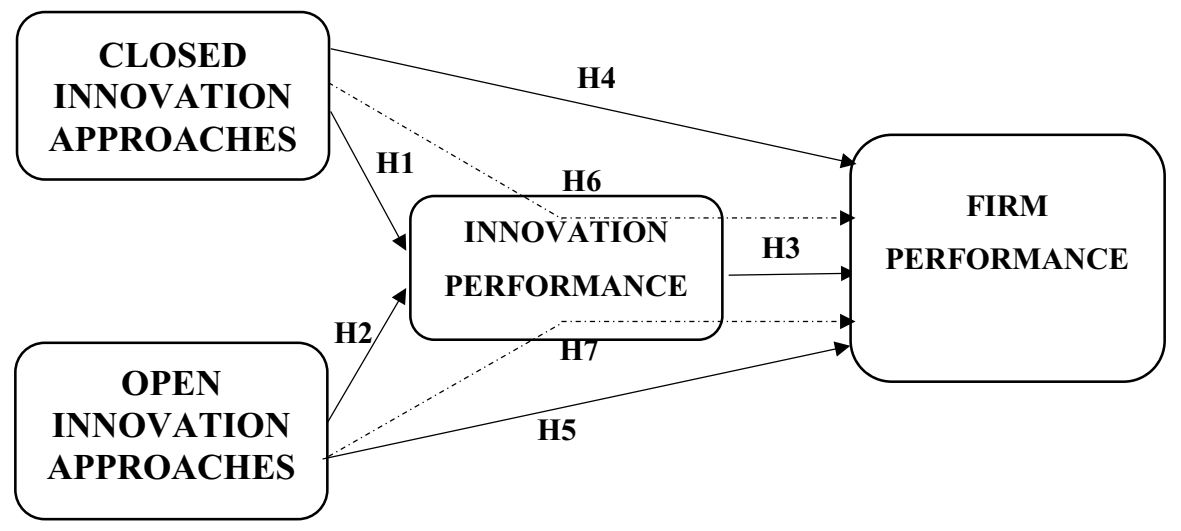

Fig. 1 Conceptual framework of the study

between the individuals from the association, including trust and participation, consequently encouraging these limits. Crema and Verbano (2013) asserted that social coordination systems are available in all phases of assimilation of information, yet they have diverse effects on innovation performance. Subsequently, like an impalpable asset, innovation performance affects firm performance, supporting the definition of seven speculations identifying with every component of intellectual capital with each measurement of innovation performance.

Organizations should adopt certain open innovation models compared with different levels of openness calculated by methods in different structures (Laursen \& Salter, 2006; Lazzarotti \& Manzini, 2009); the review must be applied in places with different dimensions of open innovation. Based on this, we hypothesize that.

$\mathbf{H}_{7}$ : Firm's innovation performance mediates between open innovation approaches and firm's performance

\section{Conceptual Framework}

Figure 1 illustrates the conceptual framework created for the study. Four-factor analyses were achieved to validate the other variables of the conceptual framework: closed innovation, open innovation, innovation performance, and firm performance because it became not feasible to define them with a singular variable. The main intention of this conceptual framework is to analyse individual variables conveniently.

\section{Research Design}

The goal is to recognize the effect of the open and closed innovation method on company innovation performance and thereby the overall firm's performance. A quantitative research approach was adopted for the study. It is often used to 
interpret statistical evaluation to identify the connection involving what is understood and learned through studies. Consequently, analysing data with quantitative strategies requires a knowledge of the relationships amongst variables through both descriptive and inferential statistics. Descriptive records allow us to draw inferences about populations and to estimate the parameters. The deductive method of evaluation or reasoning includes exploring theories, developing a theoretical framework or hypotheses, and confirmation of selected logically drawn premises (Browne \& Cudeck, 1992).

\section{Development of Research Instrument}

A research questionnaire was designed to study India's biotechnology industry and administered with a Google Form's assistance. The existing constructs and measures were chosen wherever possible. In this paper, the adoption of innovation practices is considered independent, while innovation performance and firm performance are considered dependent variables. Furthermore, innovation performance also acts as a mediating variable to analyse the mediating effects of open and closed innovation approaches on firm performance. The independent variables, such as open innovation practices and closed innovation practices operationalized by Chesbrough (2006) and Hungund and Mani (2019), were adopted. The dependent variable to measure innovation performance was adopted from previous researchers (Agostini et al., 2015; Kang \& Park, 2012). The mediating variable used here is the innovation performance factor. The innovation performance is measured using patents, copyrights, and trademarks (Rakthai et al., 2019; Kim \& Choi, 2018). The dependent variables to measure firm performance factors that were first introduced by Bollen et al. (2005), Wadho and Chaudhary (2018), Clarke et al. (2011), and Chen et al. (2005) are also used in our study.

A web-based survey was conducted via email, and the survey was covered by direct interviews with decision-makers from several biotechnology companies, where possible by a structured questionnaire replica.

\section{Data Collection and Sampling Plan}

The data for this study was provided by the Department of Biotechnology (DBT) in India, the government-run enterprise in the management and marketing field of biotechnology in India, BIRAC, Manipal University Technology Business Incubator (MUTBI), and Confederation of Indian Industry (CII). The analysis of the populace consists of all the biotechnology firms located in India. These companies were of several types, including healthcare, research, and pharmaceutical. Regarding the population setting, every organization had to consult extensively available sources to encourage replicability and pay attention to the manufacturing industry as development is the highest investigation in the open literature on innovation. This study took into account a selection of 200 biotechnology companies from across India. A snowball sampling was used to reach samples to ensure the sample's representativeness 
Table 1 Construct, composite reliability, and average variance extracted

\begin{tabular}{lllll}
\hline S. no & Construct & Cronbach's alpha & $\begin{array}{l}\text { Average variance } \\
\text { extracted }\end{array}$ & $\begin{array}{l}\text { Composite } \\
\text { reliability }\end{array}$ \\
\hline 1 & Innovation approaches & 0.843 & 0.52 & 0.93 \\
2 & Innovation performance & 0.795 & 0.51 & 0.84 \\
3 & Firm performance & 0.866 & 0.55 & 0.88 \\
4 & Overall & 0.962 & 0.66 & 0.94 \\
\hline
\end{tabular}

and generalisability. A standard questionnaire link was sent to the respondents. Some data particularly addressed to senior managers or equivalent, have also been collected using the personal interview method in Google form to the participants. The questionnaire consisted of questions on collaborative activities for innovation, intellectual property rights, and partnerships during their tenure were included in the questionnaire. The questionnaire's different factors cantered on employer traits, open innovation approaches adopted, its influence on innovation performance, and the consequences on overall firm performance. Answers are measured on a 7-point Likert scale, ranging from 1= "Strongly Disagree" to 7 = "Strongly Agree."

\section{Result Analysis}

A sequence of statistical tests, including mediation modelling using SPSS 23 with Process Macro version 3.3, was conducted to test the hypotheses. Keeping in mind the investigations of Hair et al. (2010) and Shah and Goldstein (2006), the model with the better goodness of fit has been chosen to depict the explored relations. Specifically, as per Medsker et al. (1994), estimations of the goodness of fit index (GFI) and comparative fit index (CFI) are 0.90 comprise satisfactory fit while following Browne and Cudeck (1992), root-mean-square error of approximation (RMSEA) is adequate given that it is somewhere in the range of 0.05 and 0.08 . The greatest probability estimation strategy has been picked conforming to Hair et al. (2010).

\section{Reliability and Validity}

To further understand the reliability of the measures studied under this research, a reliability and validity construct was created. The most suitable values used to understand the objective were isolated and analysed (Gerbing \& Anderson, 1988; Alegre et al., 2008; Gatignon et al., 2002). Furthermore, the confirmatory factor analysis (CFA) was utilized to analyse the dimensionality, quality, and legitimacy of various measures used in this study. The fit indices recommended that the model gave an agreeable fit to the data. All the factor loadings were exceedingly significant $(p<0.000)$, and the composite reliability values have visibly exceeded the base value of 0.7, implying consistency throughout the framework (Bagozzi \& Yi, 1988). The average variable extracted (AVE) for all the constructs also exceeded 0.5. In this way, the measures exhibit adequate reliability. (see Table 1) 
Hair et al. (2010) notes that it is possible to determine the discriminant variability focused on three parameters integrating factor ties that include average shared variance (ASV), maximum shared variance (MSV), and whether AVE's square root is more prominent than the inter-variable relationships. Convergent validity was studied by focusing on the factor loading of measures. High significance extracted and loading variances changes over the $50 \%$ range demonstrated that the estimation error is lower than the convergent validity (Shook et al., 2004). Discriminant validity was studied, contrasting the squared inter-construct connections to the extracted variance. Squared inter-construct values show the fluctuation shared by two different constructs. If these values were significantly higher than the separated change, just one variable exists (Fornell \& Larcker, 1981). Composite reliability was determined along with Cronbach's alpha because the quantity of factors studied utilized this reliability index (Pedhazur \& Schmelkin, 1991). Composite reliability was also analysed to be at most 0.7 (Hair et al., 2005). Given the differing degrees of freedom, the model is checked for value and chi-square variations. Models with lower chisquares are favoured in the event of factually significant comparisons (Chen et al., 2005).

\section{Descriptive Statistics}

The respondents for the survey were from all age group categories, with less than 30 to above 50 . However, close to $50 \%$ of the respondents were in the age group of 31-40. Furthermore, the different periods of the associations are also studied. Both old and new firms have been analyzed in this paper. The firm ages range from $<5$ years to more than 20 years, with most respondents less than 20 years of age category.

On the other hand, different types of biotechnological firms are also studied. This category is divided into 19 groups, based on the business they do. Most biotechnology companies considered are pharmaceutical organizations, as they account for more than 29 percent of the total companies studied. Following is the table analysing the types of companies and respondent age profile.

Table 2 represents the most common company type and age considered for the study. Pharmaceutical, food industry, and research were the most common company types considered, along with companies above 20 years.

Figure 2 exhibits the distinctive open innovation practices embraced by these biotechnological firms in India. A large part of the organizations has adopted collaboration as an open innovation practice. Some organizations have also sought to incorporate these activities to boost the level of innovation and, therefore, the organizations' firm performance.

The chi-square difference was measurably critical $(p<0.001)$, and the lower chi-square value affirms the prevalence of the dimensional model as analyzed from the SEM analysis. Validity and reliability analyses likewise show the model as preferred. The model demonstrated legitimacy and reliability. All loadings were 
Table 2 Company type and age

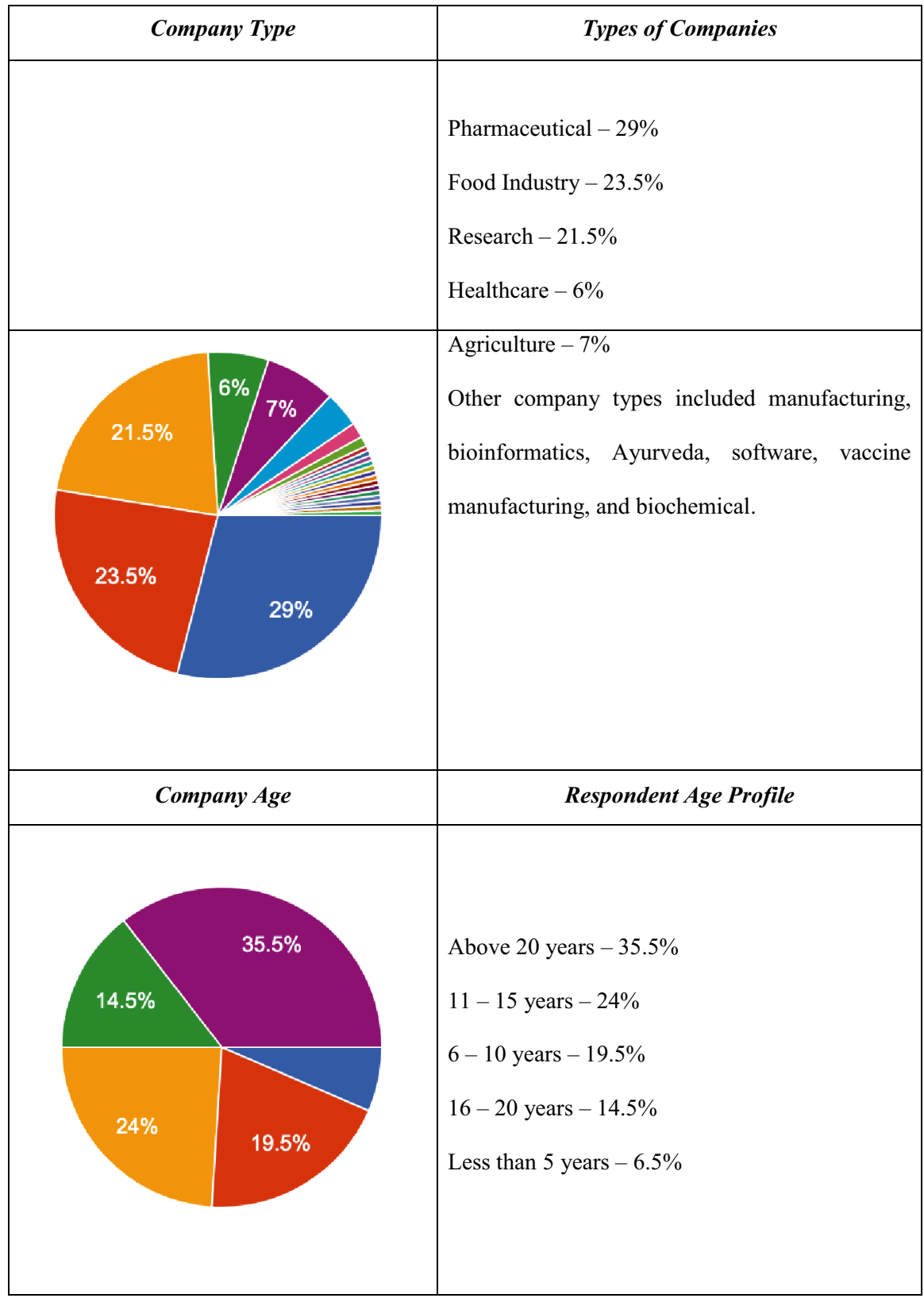

positive, higher than 0.55 , and statistically different from zero $(p<0.001)$, and the variance extracted in each case was above 50\% (Hair et al., 1995). All measurements had values above 0.80 . 


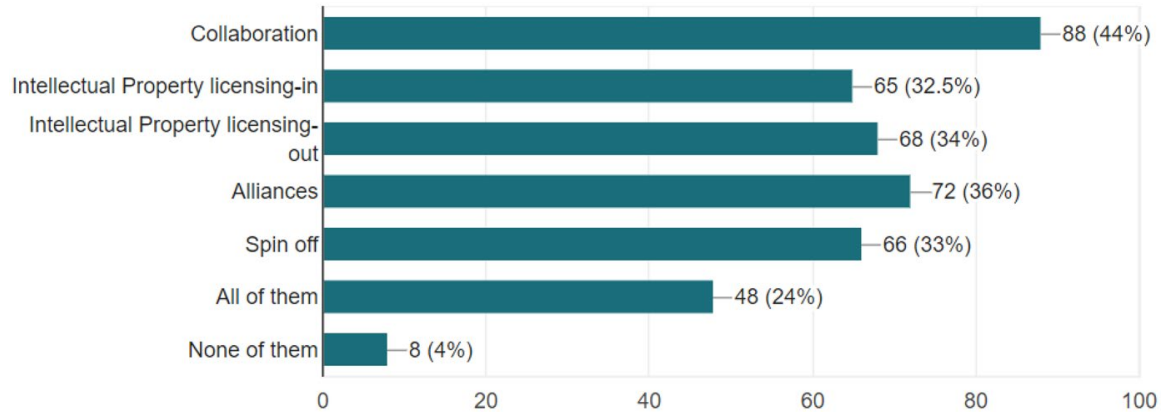

Fig. 2 Adoption of open innovation practices

CMIN/DF minimum discrepancy by the degree of freedom, CFI comparative fit index, GFI goodness of fit index, TLI Tucker-Lewis index, RMSEA root-meansquare error of approximation.

\section{Structural Model}

To test our hypothesis between the latent variables, structural equation modelling utilizing the IBM Amos 23 software with the maximum likelihood estimation parameter is used. The hypothetical model is examined depending on the fit between the theoretical model and the information through the fit index. These records are prevalently known as Bentler and Bonett (1980) non-normed fit index (NNFI), goodness-of-fit index (GFI), Bentler \& Bonett (1980) comparative fit index (CFI), and root-mean-square error of approximation (RMSEA) (Bentler \& Bonett, 1980). As per Hair et al. (2010), the qualities 0.90 or more for CFI and GFI and qualities underneath 0.08 for RMSEA propose a satisfactory fit between the speculated model and the information. Four measures estimate the latent constructs CI, OI, IP, and FP. The first order's fit records remain at $\chi 2$ (DF): 2.223, CFI: 0.846, GFI: 0.819, and RMSEA: 0.078, indicating good fit (Table 2). All the factor loadings are critical at $p<0.001$, showing the builds' focalized legitimacy (Hair et al., 2010).

The first-order confirmatory factor analysis is performed to see the significance of every measure exclusively with the end goal to comprehend the effect of innovation on firm performance (Lichtenthaler \& Lichtenthaler, 2008). The first-order model's fit indices (Table 3) indicate better model fit when contrasted with the firstorder model. All the latent variables (CI, OI, IP, and FP) are significant. The path

Table 3 Model fit indices

\begin{tabular}{lllllll}
\hline S. no & Model & CMIN/DF & CFI & GFI & TLI & RMSEA \\
\hline 1 & Default & 2.223 & 0.846 & 0.819 & 0.826 & 0.078 \\
2 & Saturated & 1.951 & 1.000 & 1.000 & 1.000 & 0.043 \\
3 & Independent & 8.044 & 0.000 & 0.272 & 0.000 & 0.188 \\
\hline
\end{tabular}




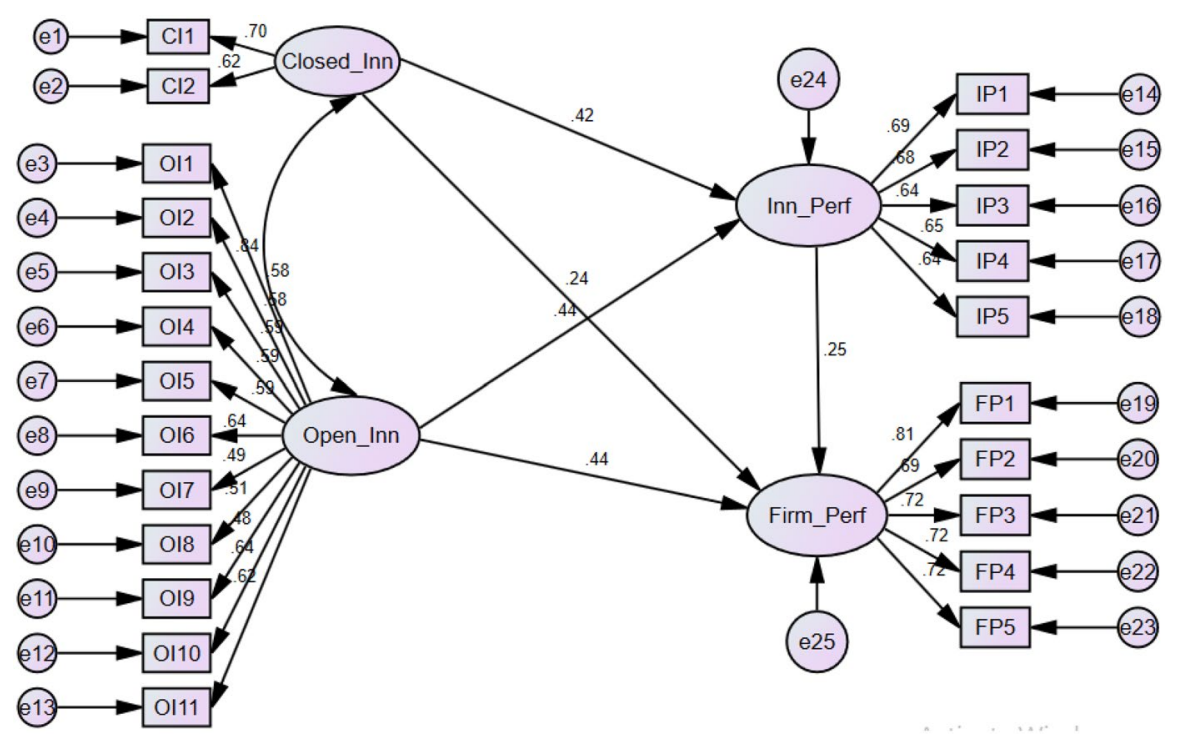

Fig. 3 Structural model

loadings of CI, OI, IP, and FP toward the firm performance of the biotechnology company in the industry portray closed innovation practices at 0.67 , open innovation practices like collaboration (0.56), intellectual property rights (0.49), alliances (0.64), a spin-off (0.63), and innovation performance (0.66). This shows the dependence of various factors on the firm performance of the company. Besides, the model passed all fit parameters: chi-squared test: $2 / \mathrm{df}(\mathrm{CMIN})=2.223$, goodness-of-fit index $(\mathrm{GFI})=0.819$, non-normed fit index $(\mathrm{NFI})=0.755$, confirmatory fit index $(\mathrm{CFI})=0.846$, and root-mean-square error approximation $(\mathrm{RMSEA})=0.078$ (Table 3). Hence, it tends to be presumed that three basic innovation measurements measure firm performance for a company.

To test our propositions (H1 to H7), structural equation modelling was performed, as illustrated in Fig. 3. The qualities in the model for $\chi 2$ (DF) 2.223, CFI 0.946, GFI 0.819, and RMSEA 0.078 show good fit (Fig. 3). Further, our outcomes demonstrate the path loading between innovation performance and firm performance at 0.10 , among innovation performance and closed innovation approaches at 0.40 , between innovation performance and open innovation approaches at $0.4,5$ and between firm performance and closed innovation approaches at 0.48 firm performance and open innovation approaches at 0.30 . All qualities are significant at $p=0.001$. The fascinating perspective is that firm performance is interceded by innovation, which can be found from mediation effects (Table 4). This results in the company's innovation success contributing to prompt company output, which has been interfered with open and closed approaches to innovation.

Furthermore, the analysis is performed through Amos 20.0, as Hayes (2013) recommended to comprehend the connection between innovation approaches and innovation performance, innovation performance and firm performance, and innovation 


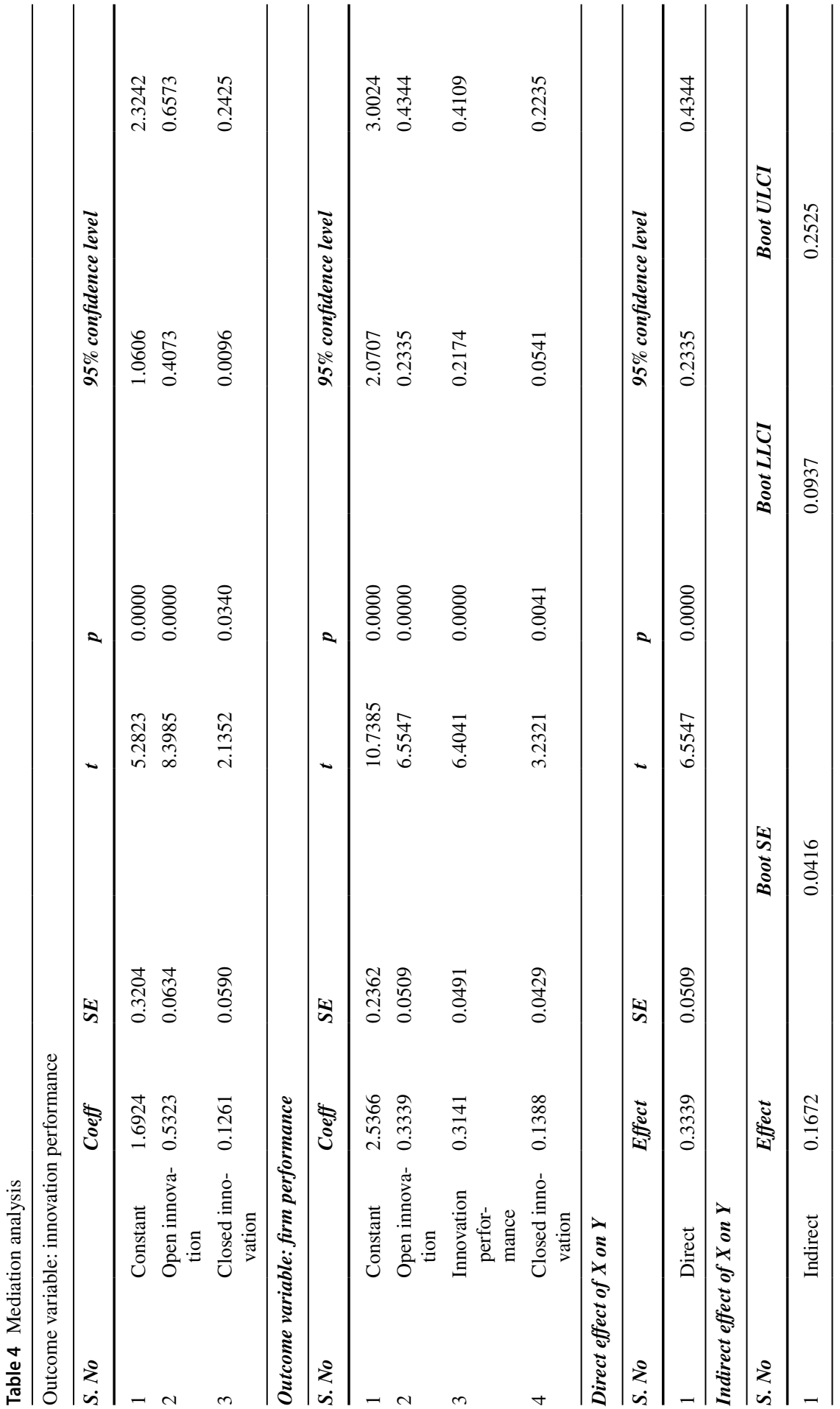


approaches and firm performance. The outcomes demonstrate that open innovation and closed innovation separately have a positive influence on firm performance.

\section{Mediation Analysis}

We made use of Hayes (2009) process macro to test for mediation using model 4. This model includes an independent variable $X$ (closed innovation and open innovation), a dependent variable $\mathrm{Y}$ (firm performance), and a mediating variable $\mathrm{M}$ (innovation performance). This test is nearly done to analyse whether the impact of innovation practices on firm performance may impart flow through a mediated variable, i.e., innovation performance. This would reflect an indirect effect within the model. The model number was set at four, confidence interval at 95, and bootstrap samples at 5000. The result indicated a mediation effect prevalently, and both open innovation practices and closed innovation practices influence innovation performance, further influencing the firm's performance. The statistical result suggests that hypotheses 6 is found to be significant and are not rejected. Furthermore, the statistical result also suggests that hypotheses 7 is found to be significant and are not rejected.

Table 4 reflects the mediation analysis of the study. For the innovation performance model, the regression coefficient is 0.53 and indicates statistical significance at the 0.05 level, so the innovation performance path to innovation performance is statistically significant. This implies that data is uniform with the notion that innovation practice applies a predictive effect on innovation performance. For the outcome variable of firm performance, this is a multiple regression component. The direct effect of innovation practice on achievement is statistically significant as well. There is some consistency within the idea that we have a mediational relationship.

Further, it is observed that the indirect effect is positive (0.1672), indicating that a positive indirect impact of innovation practice on firm performance via the mediator innovation performance at a 95\% confidence level. The null hypothesis is that the indirect effect is equal to zero. Therefore, if the null hypothesis's indirect impact falls between the lower and the upper limits, the null hypothesis is kept being effectively zero in the population. As zero falls outside of the bounds, it is inferred that the indirect effect is significantly different from zero within the population. Therefore, innovation performance acts as a mediating entity and thus influences firm performance.

\section{Discussion and Managerial Implications}

\section{Discussions}

In accordance with Firer and Williams (2003), Lichtenthaler \& Lichtenthaler (2008) and West and Bogers (2013), a few biotechnological firms still rely on a direct strategy as partnerships rely solely on internal R\&D for generating ideas. Also, Indian biotechnological companies found that another way to deal with 
innovation is working on client issues and searching for innovations or ideas and knowledge remotely (Conboy \& Morgan, 2011). The outcomes demonstrate that the firm's closed innovation approaches to the reception of innovation performance are positively related. This implies that firms accept that practicing closed innovation is also an important factor in improving the firm's innovation performance. Although it can be inferred from the fact that more businesses are more likely to pursue innovative approaches because of their advantages, conventional biotechnology companies are inclined to pursue a closed approach to innovation to maximize their innovation performance. The examination results demonstrate that closed innovation, in turn, impacts the innovation performance of the firm. This outcome agrees alongside West and Gallagher (2006) outcomes and Enkel and Gassmann (2010). Old and traditional biotechnological firms in India that are generally new are not as inclined to innovation methods as new firms. This suggests more established firms are leaning more toward closed innovation to improve their innovation performance.

As per the study, adoption of open innovation practices such as internal R \& D with external collaboration, participation in innovative trade shows for idea generation, forming alliances for new product development and spin-off products to attract a new market have a positive impact on the innovation performance of the firm. These practices are significant when it comes to open innovation practices for biotechnological firms. The reception of open innovation practices is, by all accounts, especially beneficial for biotechnological firms that can utilize the learning and progress created by different organizations and shared through associations and unions to empower innovation procedures. The lack of resources and skills, which are often mentioned, is also an obstacle to innovative processes. Opening up the limits outside will enable businesses of restricted size to last and expand on the global market, increasing the firm's efficiency using the tools for licensing and sharing intellectual property, collaborations, and alliances with suppliers, customers, and different organizations. The findings show that open innovation success affects the company's innovation performance. This proposes the adoption of open innovation approaches contrasted with the adoption of both innovation practices positively impacts innovation performance. These outcomes on the impact of open innovation are concurrent with Chesbrough and Crowther's (2006) findings that affirm open innovation practices (primarily collaboration and intellectual property rights) measure as a significant factor in a company's innovation outcome measure. Subsequently, the examination result further agrees with the outcomes of Chesbrough (2003a), Chesbrough (2006), and Laursen and Salter (2006). The outcomes likewise demonstrate that the utilization of open innovation practices positively impacts the innovation performance output directly.

Of the innovation performance factors, biotechnological firms utilise copyrights, trademarks, patents, trade secrets and publicity rights which thereby increase the firm performance of the company. Chen et al. (2005) showed that innovative performance plays a positive role between innovative acts and firm performance in Turkish manufacturing enterprises which has been further corroborated by this study for Indian biotechnological firms. 
Biotechnological and big pharmaceutical firms are known to invest heavily in $\mathrm{R} \& \mathrm{D}$ of the companies and tend to focus on internal structures for progress. This is an existing method of improving firm performance (Chesbrough \& Euchner, 2011; Chesbrough, 2012). This is clearly analysed in this study that existing biotechnological firms also adopt closed innovation approaches which thereby have a positive impact on the firm performance of the company. The outcome shows that accentuation on $\mathrm{R} \& \mathrm{D}$ (closed innovation practices) is vast to improve firm performance. This demonstrates that biotechnological firms in India who are more inclined to emphasize the company's R \& D departments and hire top employees positively impact firm performance. The outcomes vary from prior examinations (Chen et al., 2005; Chesbrough \& Euchner, 2011). Development technique appears to be most appropriate to embrace distinctive approaches to improve firm performance, trailed by the methodology of proficiency by broadening procedure, which is fundamentally focused on the opening to the outside. This is steady with past investigations of Tidd and Trewhella (1997) that, concentrating on an example of extensive firms in the UK and Japan, showed that organizations with a separation methodology grow more inner R\&D assets than organizations that seek after a supporter technique. As recently examined, internal capabilities are incredibly essential to accomplish vital development objectives, to discover the correct outside assets, finishing and coordinating them properly.

So as to improve on the existing innovation practices, biotechnological firms moved focus on open innovation practices to improve the firm performance. In this study, open innovation practices such as inclusion of collaboration and spin-off products have a direct impact on firm performance factors such as business development and new product development. It can be affirmed that open innovation approaches further have a positive impact on firm performance. This is in line with the research of Clarke et al. (2011) and Bianchi et al. (2011).

This study also proposes a positive effect of the mediating role of innovation performance on firm performance. This is further seen in research conducted by Lofsten (2014), Wadho and Chaudhry (2018), and Amin and Aslam (2017). From this study, it is seen that for Indian biotechnological firms, innovation performance acts as an essential component in business. It serves as a vital method for the creation and building of new markets. Hence, innovation performance is presented between innovation approaches (both closed and open) and firm performance to encourage organizations' performance.

The outcome demonstrates that a company's innovation performance acts as a mediator between the company's innovation practices and firm performance. The significance is positive. This shows that biotechnology firms deliver a positive increase in innovation performance on adopting both closed and open innovation practices, thereby influencing firm performance. The outcomes demonstrate that innovation performance factors individually are a significant impacting factor in firm performance analysis. The results vary from the prior investigations (Amin \& Aslam, 2017; Chen et al., 2005; Löfsten, 2014; Michelino et al., 2016; Wadho \& Chaudhry, 2018). Biotechnological firms that spotlight a positive effect of both innovation practices on innovation performance find that the innovation performance factor, in turn, acts as a mediator and improves firm performance. 
The consequences of this paper demonstrate that biotechnological firms in India embracing an aggressive technique of collaboration (open innovation) are inclined towards a better performance of the firm. This result is concurrence with past examinations (Hungund \& Kiran, 2017; Rakthai et al., 2019). Secondly, biotechnology companies embracing an expansion in market technique using specific collaborations like trade shows do not advance interior ability. However, they accentuate the working of a system of other parameters. The model also incorporates the empowering components of open innovation: collaboration and alliance practices, the relevant variables (patents, trademarks, and trade secrets), enhancing the decency of the model.

\section{Managerial Implications}

The paper highlights a few features as critical facts for managers and higher authorities concerning open innovation administrative practices. The difficulties that originate from several collaborations are a little off, and the assets (time and money) are needed to assemble the communitarian plan. In such circumstances, a director will, in all probability, wind up mindful, of various powers endeavouring to pull the cooperation in multiple ways and may encounter dissatisfaction concerning the trouble of settling on choices and advancing. In such circumstances, the firm can profit by contemplating the administrative practices depicted in this proposition, as they may offer methods for managing these difficulties.

In that, the administration may vary from an unmixed progression of exercises. Mainly as a method of being and related, leaders (and other specialists) could be doing more attentive practices that affect others and conceive various functions. Thus, the harmony that the administrator strikes reverberates all through the association. Being a "reflexive professional" and setting aside the opportunity to consider one's activities and their impact can empower directors to impact authoritative activity in more ponder ways.

From stakeholders, businesses engaging in open collaboration with innovators will gain through exploring what is relevant and intent by engaging in open collaboration in innovation at different association levels. In either case, open innovation collaboration often ensures that the strategies previously chosen may be reconsidered due to the partnership. An agreement should occur to deal with these changes within the company if this situation arises. Furthermore, it becomes familiar that the open innovation initiative is not adopted in the firm in the conventional sense. It should be possible for people to collaborate most efficiently for an ambiguous pair of rules and unbending frameworks.

\section{Conclusion and Limitations}

The study outcomes supplement existing open and closed innovation by showcasing the different affiliation that links both internal and external measurements of innovation approaches (open and close), innovation performance, and organizational 
performance by reviewing biotechnological organizations in India. The conclusions provide suggestions and ramifications for both theory and practice independently.

The paper speaks on how organizations in any industry compose themselves to actualize open innovation and closed innovation and its significant effect on firm and innovation performance. Specifically, it examines the biotechnological industry's example as it speaks to a ripe ground to select the open innovation logic and its effects. Biotechnological firms in India have generally made broad collaborative efforts to help in their new item improvement process. The research records about two improvements that can be expected with the open innovation trend when dealing with the entombing hierarchical exchange in inventions and learning:

The study organizations have steadily altered their innovation network by including an ever-increasing number of outer associates working outside their main territories, therefore supporting an idea of open innovation approach. The sources and employments of innovation have been received, and alliances assume an expanding job among the hierarchical modes executed by firms in the study. In this manner, supporting firms are increasingly vital in hunting down frailties connecting their innovation procedure to outer performing artists in an ordinary open innovation approach.

The paper gives a comprehensive study of how biotechnological firms have mainly used various hierarchical modes (i.e., intellectual property licensing, alliances, buy, purchase, and supply of specific and consistent knowledge and even administrations) to go into a relationship with different sorts of associates (i.e., large pharmaceutical organizations, biotechnology research-based firms, platform biotech firms, and academic institutions) with the hope to anchor an increase in innovation performance of the company thereby affecting the firm performance. Attentive understanding of how the attributes of the biotechnological business (e.g., the structure of the development procedure and its run of the mill hazard design, the business focal point of industry players on actual remedial regions, the issues identified with the administration of Intellectual Property) affects how firms execute open innovation has been progressed too. In this regard, the paper underpins the possibility that the absence of comparative commitments in the literature is an essential gap in the ebb and flow to explore the open innovation paradigm's usage. To the extent the paper's impediments are involved, it is necessary to see that the study is exploratory.

A potential road for future research can be a precise examination of the factors that have decided the watched transient innovation in the hierarchical modes for open innovation embraced by biotechnological firms. First of all, our objective is restricted to the research of selected biotechnology firms in India. Although biotechnology firms such as pharmaceutical firms associate and form a unit with the best level global organizations, these are not as vast, nor do these companies have the equivalent complex technical and marketing abilities as their competitors. This examination is restricted to investigating the impact of innovation approaches on innovation performance, influencing firm performance. Furthermore, the investigation should discover the effect of the firm's firm execution on the firm's economic performance. This will further give the organization an aggressive superiority over its opposition and help enhance its GDP. 
Finally, although this analysis focuses on the directions of innovation and business performance, more studies may explore other potentially directive effects of possible elements influencing the relation between innovation and business performance of different companies.

Funding Open access funding provided by Manipal Academy of Higher Education, Manipal

Open Access This article is licensed under a Creative Commons Attribution 4.0 International License, which permits use, sharing, adaptation, distribution and reproduction in any medium or format, as long as you give appropriate credit to the original author(s) and the source, provide a link to the Creative Commons licence, and indicate if changes were made. The images or other third party material in this article are included in the article's Creative Commons licence, unless indicated otherwise in a credit line to the material. If material is not included in the article's Creative Commons licence and your intended use is not permitted by statutory regulation or exceeds the permitted use, you will need to obtain permission directly from the copyright holder. To view a copy of this licence, visit http://creativecommons.org/licenses/ by/4.0/.

\section{References}

Agostini, L., Caviggioli, F., Filippini, R., \& Nosella, A. (2015). Does patenting influence SME sales performance? A Quantity and Quality Analysis of Patents in Northern Italy. European Journal of Innovation Management, 18(2), 238-257.

Agostini, L., Filippini, R., \& Nosella, A. (2014). Corporate and product brands: Do they improve SMEs performance? Measuring Business Excellence, 18(1), 78-91.

Alegre, J., Lapiedra, R., \& Chiva, R. (2008). A measurement scale for product innovation performance. European Journal of Innovation Management, 9, 333-46.

Amin, S., \& Aslam, S. (2017). Intellectual capital, innovation and firm performance of pharmaceuticals: A study of the London stock exchange. Journal of Information \& Knowledge Management, 16(2), 1750017. https://doi.org/10.1142/s0219649217500174

Bagozzi, R. P., \& Yi, Y. (1988). On the evaluation of structural equation models. Journal of the Academy of Marketing Science, 16(1), 74-94.

Belderbos, R., Carree, M., \& Lokshin, B. (2004). Cooperative R\&D and firm performance. Research Policy, 33(10), 1477-1492. https://doi.org/10.1016/j.respol.2004.07.003

Bengtsson, L., Lakemond, N., Lazzarotti, V., Manzini, R., Pellegrini, L., \& Tell, F. (2015). Open to a select few? Matching Partners and Knowledge Content for Open Innovation Performance. Creativity and Innovation Management, 24(1), 72-86.

Bentler, P., \& Bonett, D. (1980). Significance tests and goodness of fit in the analysis of covariance structures. Psychological Bulletin, 88(3), 588-606. https://doi.org/10.1037//0033-2909.88.3.588

Bianchi, M., Cavaliere, A., Chiaroni, D., Frattini, F., \& Chiesa, V. (2011). Organisational modes for Open Innovation in the bio-pharmaceutical industry: An exploratory analysis. Technovation, 31(1), 22-33.

Bogers, M. (2011). The open innovation paradox: Knowledge sharing and protection in R\&D collaborations. European Journal of Innovation Management, 14(1), 93-117.

Bollen, L., Vergauwen, P., \& Schnieders, S. (2005). Linking intellectual capital and intellectual.

Browne, M. W., \& Cudeck, R. (1992). Alternative ways of assessing model fit. Sociological Methods and Research, 21(2), 230-258.

Bruton, G., \& Rubanik, Y. (2002). Resources of the firm, Russian high-technology startups, and firm growth. Journal of Business Venturing, 17(6), 553-576. https://doi.org/10.1016/s0883-9026(01) 00079-9

Burpitt, W. J., \& Bigoness, W. (1997). Leadership and innovation among teams - the impact of empowerment. Small Group Research, 3, 414-423.

Caputo, M., Lamberti, E., Cammarano, A., \& Michelino, F. (2016). Exploring the impact of open innovation on firm performances. Management Decision, 54(7), 1788-1812. 
Chaston, I., \& Scott, G. (2012). Entrepreneurship and open innovation in an emerging economy. Management Decision, 50(7), 1161-1177. https://doi.org/10.1108/00251741211246941

Chen, M. C., Cheng, S. J., \& Hwang, Y. (2005). An empirical investigation of the relationship between intellectual capital and firms' market value and financial performance. Journal of Intellectual Capital, 6(2), 159-176.

Chesbrough, H. (2003a). The era of open innovation. Sloan Management Review, 44(3), 35-41.

Chesbrough, H. (2003b). Open innovation: The new imperative for creating and profiting from technology. Harvard Business School Press.

Chesbrough, H. (2006). The logic of open innovation: Managing intellectual property. California Management Review, 45(3), 33-58.

Chesbrough, H. (2007). The market for innovation: Implications for corporate strategy. California Management Review, 49(3), 45-66.

Chesbrough, H. (2012). Open innovation: Where we've been and where we're going. Research-Technology Management, 55(4), 20-27. https://doi.org/10.5437/08956308x5504085

Chesbrough, H., \& Crowther, A. (2006). Beyond high tech: Early adopters of open innovation in other industries. $R$ and D Management, 36(3), 229-236. https://doi.org/10.1111/j.1467-9310.2006.00428

Chesbrough, H., \& Euchner, J. (2011). Open services innovation: An interview with Henry Chesbrough. Research Technology Management, 54(2), 12-17.

Chiang, Y. H., \& Hung, K. P. (2010). Exploring open search strategies and perceived innovation performance from the perspective of inter-organizational knowledge flows. R\&D Management, 40(3), 292-299.

Clarke, M., Seng, D., \& Whiting, R. H. (2011). Intellectual capital and firm performance in Australia. Journal of Intellectual Capital, 12(4), 505-530. https://doi.org/10.1108/14691931111181706

Cohen, W., \& Levinthal, D. (2009). Innovation and learning: The two faces of R \& D. The Economic Journal, 99(397), 569. https://doi.org/10.2307/2233763

Conboy, K., \& Morgan, L. (2011). Beyond the customer: Opening the agile systems development process. Information and Software Technology, 53(5), 535-542. https://doi.org/10.1016/j.infsof.2010.10.007

Crema, M., \& Verbano, C. (2013). The influence of technology innovation strategy on intangible assets and their impact on innovation performance, presented at Global Innovation and Knowledge Academy - GIKA 2013, 9-11 July, University of Valencia.

Darroch, J. (2005). Knowledge management, innovation and firm performance. Journal of Knowledge Management, 9(3), 101-115.

De Brentani, U., \& Kleinschmidt, E. J. (2004). Corporate culture and commitment: Impact on performance of international new product development programs. Journal of Product Innovation Management, 21(5), 309-333.

Dreschler, W., \& Natter, M. (2012). Understanding a firm's openness decisions in innovation. Journal of Business Research, 65(3), 438-445.

Enkel, E., \& Bader, K. (2012). How does business strategy influence innovation? Performance, 4(2), 46-55.

Enkel, E., \& Gassmann, O. (2010). Creative imitation: Exploring the case of cross-industry innovation. $R \& D$ Management, 40(3), 256-270.

Enkel, E., Gassmann, O., \& Chesbrough, H. (2009). Open R\&D and open innovation: Exploring the phenomenon. $R \& D$ Management, 39(4), 311-316.

Firer, S., \& Williams, S. M. (2003). Intellectual capital and traditional measures of corporate performance. Journal of Intellectual Capital, 4(3), 348-360.

Fornell, C., \& Larcker, D. F. (1981). Evaluating structural equations models with unobservable variables and measurement error. Journal of Marketing Research, 18(1), 39-50. https://doi.org/10.2307/ 3151312

Gatignon, H., Tushman, M. L., Smith, W., \& Anderson, P. (2002). A structural approach to assessing innovation: Construct development of innovation locus, type, and characteristics. Management Science, 48(9), 1103-1122.

Gerbing, D., \& Anderson, J. (1988). An updated paradigm for scale development incorporating unidimensionality and its assessment. Journal of Marketing Research, 25(2), 186. https://doi.org/10. $2307 / 3172650$

Guthrie, J., \& Petty, R. (2000). Intellectual capital: Australian annual reporting practices. Journal of Intellectual Capital, 1(3), 241-251.

Hair, F., Anderson, E., Tahtham, L., \& Black, C. (1995). Multivariate Data Analysis with Readings (4th ed.). New Delhi: Prentice-Hall. 
Hair, J. F., Anderson, R. E., Tatham, R. L., \& Black, W. C. (2005). Multivariate Data Analysis. New Jersey: Prentice-Hall.

Hair, J. F., Black, W. C., Babin, B. J., \& Anderson, R. E. (2010). Multivariate Data Analysis, 7. Prentice Hall.

Hayes, A. F. (2009). Beyond Baron and Kenny: Statistical mediation analysis in the new millennium. Communication Monographs, 76(4), 408-420.

Hayes, A. F. (2013). Introduction to Mediation, Moderation, and Conditional Process Analysis: A Regression-Based Approach (1st ed.). New York: The Guilford Press.

Huang, Y., Chung, H., \& Lin, C. (2009). R\&D sourcing strategies: Determinants and consequences. Technovation, 29, 155-169.

Hungund, S., \& Kiran, K. B. (2017). Open innovation practices among Indian software product firms: A pilot study. International Journal of Innovation and Sustainable Development, 11(4), 355-376.

Hungund, S., \& Mani, V. (2019). Benchmarking of factors influencing adoption of innovation in software product SMEs: An empirical evidence from India. Benchmarking: An International Journal.

Hurmelinna-Laukkanen, P., Sainio, L. M., \& Jauhiainen, T. (2008). Appropriability regime for radical and incremental innovations. R\&D Management, 38(3), 278-289.

Inauen, M., \& Schenker-Wicki, A. (2011). The impact of outside-in open innovation on innovation performance. European Journal of Innovation Management, 14(4), 496-520. https://doi.org/10. $1108 / 14601061111174934$

Jaekel, M., Wallin, A., \& Isomursu, M. (2015). Guiding networked innovation projects towards commercial success-A case study of an EU innovation programme with implications for targeted open innovation. Journal of the Knowledge Economy, 6(3), 625-639. https://doi.org/10.1007/ s13132-015-0274-3

Kafouros, M., \& Forsan, N. (2012). The role of open innovation in emerging economies: Do companies profit from the scientific knowledge of others? Journal of World Business, 47, 362-370.

Kang, K. N., \& Park, H. (2012). Influence of government R\&D support and inter-firm collaborations on innovation in Korean biotechnology SMEs. Technovation, 32(1), 68-78.

Katila, R., \& Ahuja, G. (2002). Something old, Something new: A longitudinal study of search behavior and new product introduction. Academy of Management Journal, 45(6), 1183-1194. https:// doi.org/10.5465/3069433

Kim, S. J., \& Choi, S. O. (2018). The effects of job mismatch on pay, job satisfaction, and performance. Journal of Open Innovation: Technology, Market, and Complexity, 4(49). https://doi.org/ 10.3390/joitmc4040049

Laursen, K., and Salter, A. (2006). Open for innovation: the role of openness in explaining innovation performance among U.K. manufacturing firms.\&nbsp;Strategic Management Journal, \&nbsp;27(2), 131-150.\&nbsp;https://doi.org/10.1002/smj.507

Lazzarotti, V., \& Manzini, R. (2009). Different modes of open innovation: A theoretical framework and an empirical study. International Journal of Innovation Management, 13(4), 615-636.

Lettl, C., Herstatt, C., \& Gemuenden, H. (2006). Learning from users for radical innovation. International Journal of Technology Management, 33(1), 25.

Lichtenthaler, U., \& Ernst, H. (2009). Opening up the innovation process: The role of technology aggressiveness. $R \& D$ Management, 39(1), 38-54.

Lichtenthaler, U., \& Lichtenthaler, E. (2008). A capability-based framework for open innovation: Complementing Absorptive capacity. Journal of Management Studies, 46(8), 1315-1338.

Löfsten, H. (2014). Product innovation processes and the trade-off between product innovation performance and business performance. European Journal of Innovation Management, 17(1), 61-84. https://doi.org/10.1108/ejim-04-2013-0034

Luoma, T., Paasi, J., \& Valkokari, K. (2010). Intellectual property in inter-organisational relationships-Findings from an interview study. International Journal of Innovation Management, 14(03), 399-414. https://doi.org/10.1142/s1363919610002702

Luukkonen, T. (2005). Variability in organisational forms of biotechnology firms. Research Policy, 34(4), 555-570. https://doi.org/10.1016/j.respol.2005.03.004

Medsker, G. J., Williams, L. J., \& Holahan, P. J. (1994). A review of current practices for evaluating causal-models in organizational-behaviour and human-resources management research. Journal of Management, 20(2), 439-464. 
Michelino, F., Cammarano, A., Lamberti, E., \& Caputo, M. (2016). Innovation strategies in the open innovation era: A multi-dimensional approach based on patent data and accounting metrics. Journal of Organizational Management Studies, 1-11.https://doi.org/10.5171/2016.845315

Nadeem, M., Gan, C., \& Nguyen, C. (2018). The importance of intellectual capital for firm performance: Evidence from Australia. Australian Accounting Review, 28(3), 334-344.

Narula, R. (2004). R\&D collaboration by SMEs: New opportunities and limitations in the face of globalisation. Technovation, 24(2), 153-161. https://doi.org/10.1016/s0166-4972(02)00045-7

Nieto, M. J., \& Santamaria, L. (2010). Technological collaboration: Bridging the innovation gap between small and large firms. Journal of Small Business Management, 48(1), 44-69.

Noor, M. N. H., Hajar, S. A., \& Idris, M. A. (2015). The determinant of non-profit external and internal effectiveness: The role of knowledge sharing, collaborative culture, and beneficiary participation. Human Service Organizations: Management, Leadership \& Governance, 39(5), 459-474.

Oltra, M., Flor, M., \& Alfaro, J. (2018). Open innovation and firm performance: The role of organizational mechanisms. Business Process Management Journal, 24(3), 814-836. https://doi.org/10. 1108/bpmj-05-2016-0098

Ortt, J. R., \& Smits, R. (2006). Innovation management: Different approaches to cope with the same trend. International Journal of Technology Management, 34(3/4), 296-318.

Pedhazur, E. J., \& Schmelkim, L. (1991). Design and analysis: An integrated approach. Lawrence Erlbaum Associates Publishers.

Perez, J. A. H., Geldes, C., Kunc, M. H., \& Flores, A. (2019). New approach to the innovation process in emerging economies: The manufacturing sector case in Chile and Peru. Technovation, 79, 35-55.

Piller, F., \& Walcher, D. (2006). Toolkits for idea competitions: A novel method to integrate users in new product development. $R \& D$ Management, 36(3), 307-318.

Prahalad, C., \& Ramaswamy, V. (2004). Co-creating unique value with customers. Strategy \& Leadership, 32(3), 4-9.

Rakthai, T., Aujirapongpan, S., \& Suanpong, K. (2019). Innovative capacity and the performance of businesses incubated in university incubator units: Empirical study from universities in Thailand. Journal of Open Innovation: Technology, Market, and Complexity, 5(2), 33. https://doi.org/10.3390/ joitmc5020033

Roberts, E. B. (2001). Benchmarking global strategic management of technology. Research-Technology Management, 44(2), 25-36.

Schumpeter, J. (1934). Capitalism, socialism, and democracy. Harper \& Row.

Schumpeter, J. (1939). Business cycles. New York u.a: McGraw-Hill.

Shah, R., \& Goldstein, S. M. (2006). Use of structural equation modelling in operations management research: Looking back and forward. Journal of Operations Management, 24(2), 148-169.

Shook, C. L., Ketchen, D. J., Hult, T. G., \& Kacmar, K. M. (2004). An assessment of the use of structural equation modelling in strategic management research. Strategic Management Journal, 25(4), 397-404. https://doi.org/10.1002/smj.385

Terziovski, M. (2003). The relationship between networking practices and business excellence: A study of small to medium enterprises (SMEs). Measuring Business Excellence, 7(2), 78-92.

Tidd, J. (2014). Introduction: Series on technology management, Open Innovation Research, Management and Practice, 23. Imperial College Press.

Tidd, J., \& Trewhella, M. (1997). Organizational and technological antecedents for knowledge acquisition and learning. R\&D Management, 27(4), 359-375. https://doi.org/10.1111/1467-9310.00071

Un, C. A., \& Rodríguez, A. (2018). Learning from R\&D outsourcing vs. learning by R\&D outsourcing. Technovation, 72, 24-33.

Van de Vrande, V., de Jong, J., Vanhaverbeke, W., \& de Rochemont, M. (2009). Open innovation in SMEs: Trends, motives and management challenges. Technovation, 29(6-7), 423-437.

Vanhaverbeke, W. (2009). Understanding the advantages of open innovation practices in corporate venturing in terms of real options. Strategic Direction, 25(6). https://doi.org/10.1108/sd.2009.05625fad. 002

Villasalero, M., \& Villasalero, M. (2018). Multi-business firms, knowledge flows and intra-network open innovations. Journal of the Knowledge Economy, 9(1), 162-179. https://doi.org/10.1007/ s13132-015-0330-Z

Vishnu, S., \& Gupta, V. (2014). Intellectual capital and firm performance of pharmaceutical firms in India. Journal of Intellectual Capital, 15(1), 83-99.

Wadho, W., \& Chaudhry, A. (2018). Innovation and firm performance in developing countries: The case of Pakistani textile and apparel manufacturers. Research Policy, 47(7), 1283-1294. 
West, J., \& Bogers, M. (2013). Leveraging external sources of innovation: A review of research on open innovation. Journal of Product Innovation Management, 31(4), 814-831.

West, J., \& Gallagher, S. (2006). Challenges of open innovation: The paradox of firm investment in opensource software. R\&D Management, 36(3), 319-331.

Xia, T., \& Roper, S. (2008). From capability to connectivity-Absorptive capacity and exploratory alliances in biopharmaceutical firms: AUS - Europe comparison. Technovation, 28, 776-785.

Publisher's Note Springer Nature remains neutral with regard to jurisdictional claims in published maps and institutional affiliations. 